Brit. J. prev. soc. Med. (1976), 30, 219-224

\title{
Influence of personal and family factors on ventilatory function of children
}

\author{
S. R. LEEDER*, R. T. CORKHILL, M. J. WYSOCKI†, AND W. W. HOLLAND \\ Department of Community Medicine, St Thomas's Hospital Medical School, St Thomas's Hospital, London
}

J. R. T. COLLEY

Department of Community Health, Bristol

\begin{abstract}
Leeder, S. R., Corkhill, R. T., Wysocki, M. J., Holland, W. W., and Colley, J. R. T. (1976). British Journal of Preventive and Social Medicine, 30, 219-224. Influence of personal and family factors on ventilatory function of children. We wanted to assess the relative influence of various personal and family factors upon the development of ventilatory function in young children. The relationship of several such factors to peak expiratory flow rates measured at the age of five years was studied in 454 children. These children were members of a birth cohort born between 1963 and 1965 in Harrow, north-west London, who were examined regularly from birth through the first five years of life. Beside its expected association with height, peak expiratory flow rate at the age of five years was also related to a lesser extent with peak expiratory flow rate in parents. Children with a history of lower respiratory illness had mean peak flow rates which were lower than those of children who escaped these illnesses. The earlier the onset of the illness and the more frequent its recurrence, the more marked its effect on ventilatory function. The group of children with a history of asthma and bronchitis had the lowest mean peak expiratory flow rate, but a history of bronchitis or pneumonia alone (that is, without asthma) was also associated with reduced ventilatory function. Respiratory illness beginning in the first year of life was the most potentially modifiable determinant of peak expiratory flow rate in children in this study.
\end{abstract}

The association of poor social circumstances and urban living with increased morbidity in children from respiratory illness has been demonstrated many times (Wahdan, 1963; Lunn, Knowelden, and Handyside, 1967; Holland et al., 1969; Colley and Reid, 1970; Colley, 1971; Bland, Holland, and Elliott, 1974) and children who suffered respiratory illness were found, in several of these studies, to have lower ventilatory function than those who escaped these illnesses. Recently, Higgins and Keller (1975) found small but statistically significant correlations between ventilatory function in children and their parents in a family study in Tecumseh.

*Present address: Department of Medicine, McMaster University Medical Centre, Hamilton, Ontario, Canada, L8S 4J9.

†Present address: Department of Epidemiology, State Institute of Hygiene, Warsaw, ul. Chocimska 24, Poland.
Cotes (1974) has also reviewed several studies of the inheritance of ventilatory function. However, little attention has been given to either the genetic or other family factors as determinants of ventilatory function in children. In this paper, we report a study of a birth cohort of children with reference to the influence and relative importance of several personal and family factors on lung function at the age of five.

\section{MeTHODS}

The sampling procedures, data collection methods, and techniques of measurement of ventilatory capacity in both children and adults are described in detail in the first paper (pages 204-205) including the numbers of children available for study during the five years. 


\section{RESULTS}

Several personal and family factors influenced peak expiratory flow rate in the children at the age of five years, including a history of bronchitis or pneumonia. Children with a history of bronchitis or pneumonia had mean peak expiratory flow rates that were lower than those in children who escaped these illnesses. The earlier the onset of the illness, the more marked was its effect on ventilatory function (Table I). The group of 56 children who suffered from bronchitis or pneumonia during the first year of life had a mean peak expiratory flow rate (adjusted for differences in sitting height) at the age of five years which was $8.5 \%$ lower $(\mathrm{P}<0.001)$ than that found in the children without this history. Children with lower respiratory illness that had begun after the first year had a mean peak expiratory flow rate by the age of five which lay between that of the children who had had thex first attack during the first year and those with no history of bronchitis or pneumonia in any yea $\vec{F}$ and differed significantly from the latter group $(0.01<\mathrm{P}<0.02)$.

When children were grouped according to bot the age of onset and recurrence of respirator illness during the first five years (Table II) the peak expiratory flow rates (adjusted for differences in sitting height) followed a trend. Children who haథ lower respiratory illness each year (Group $\overrightarrow{\tau_{i}}$ Table II) had the lowest mean of $131 \cdot 5$ litres/mid which differed significantly $(14 \%$ lower; $P<0.00$ 至 from the mean peak flow rate of children with no attacks (Group 1, Table II). Children with on two or three subsequent episodes after the first

TABLE I

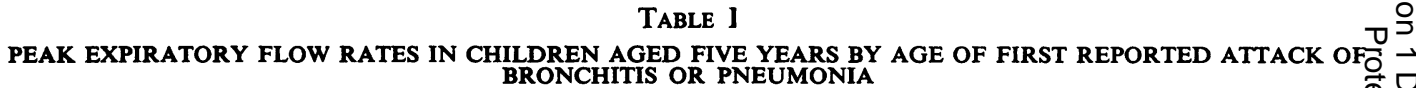

\begin{tabular}{|c|c|c|c|c|c|}
\hline Age at First Attack & $\begin{array}{l}\text { Mean PEFR } \ddagger \text { for } \\
\text { Group (litres/min) }\end{array}$ & Population* & $\begin{array}{l}\text { Standard error } \\
\text { of Means }\end{array}$ & \multicolumn{2}{|c|}{$\begin{array}{l}\text { Significance of Difference between Meas } \\
\text { of Groups With and Without Sympton }\end{array}$} \\
\hline & & & & $t$ & $\mathbf{P}$ \\
\hline No attack & $151 \cdot 3$ & 335 & $1 \cdot 4$ & - & - \\
\hline Under 1 year & $138 \cdot 5$ & 56 & $3 \cdot 5$ & $3 \cdot 41$ & $P<0.001$ \\
\hline Between 1 and 5 years & $142 \cdot 2$ & 63 & $3 \cdot 3$ & $2 \cdot 55$ & $0.01<P<0.02$. \\
\hline Total & - & 454 & - & - & - \\
\hline
\end{tabular}

Excludes 169 children who had incomplete data for the full five years or incomplete annual PEFR measurements. † Standardized by sex and sitting height at age five years.

TABLE II

PEAK EXPIRATORY FLOW RATES IN CHILDREN AGED FIVE YEARS BY HISTORY OF ANNUALLY REPORTED ATTACK OF RESPIRATORY ILLNESS $\dagger$

\begin{tabular}{|c|c|c|c|c|c|}
\hline $\begin{array}{l}\text { Age at First Report of Attack of } \\
\text { Respiratory Illness }\end{array}$ & Group & $\begin{array}{l}\text { No. of Years in which } \\
\text { Respiratory Illness Occurred }\end{array}$ & $\begin{array}{l}\text { Mean PEFR * for } \\
\text { Group (litres } / \mathrm{min})\end{array}$ & Population $\ddagger$ & $\begin{array}{c}\text { Standard Error } \\
\text { of Mean }\end{array}$ \\
\hline No attack & 1 & Nil & $152 \cdot 3$ & 121 & $2 \cdot 3$ \\
\hline One year & $\begin{array}{l}2 \\
3 \\
4\end{array}$ & $\begin{array}{l}\text { Four or five } \\
\text { Two or three } \\
\text { One }\end{array}$ & $\begin{array}{l}131 \cdot 5 \\
137 \cdot 6 \\
148 \cdot 5\end{array}$ & $\begin{array}{l}26 \\
48 \\
15\end{array}$ & $\begin{array}{l}5 \cdot 1 \\
3 \cdot 7 \\
6 \cdot 6\end{array}$ \\
\hline Two years & $\begin{array}{l}5 \\
6\end{array}$ & $\begin{array}{l}\text { Three or four } \\
\text { Two }\end{array}$ & $\begin{array}{l}140 \cdot 5 \\
148 \cdot 1\end{array}$ & $\begin{array}{l}27 \\
10\end{array}$ & $\begin{array}{l}5 \cdot 0 \\
8 \cdot 2\end{array}$ \\
\hline Three years & $\begin{array}{l}7 \\
8\end{array}$ & $\begin{array}{l}\text { Three } \\
\text { Two }\end{array}$ & $\begin{array}{l}149 \cdot 7 \\
157 \cdot 0\end{array}$ & $\begin{array}{l}50 \\
40\end{array}$ & $\begin{array}{l}3 \cdot 6 \\
4 \cdot 1\end{array}$ \\
\hline Four years & 9 & Two & $153 \cdot 7$ & 27 & $5 \cdot 0$ \\
\hline Between two and five years & 10 & One & $150 \cdot 2$ & 90 & $2 \cdot 7$ \\
\hline Total & - & & - & 454 & $\frac{\text { 을 }}{\text { D }}$ \\
\hline
\end{tabular}


year also had significant, although smaller, reductions in mean peak flow rate. Illness which was recurrent in consecutive years was not consistently associated with a more marked reduction in peak expiratory flow rate. However, the earlier illnesses began, the larger the deficits in ventilatory function especially when those illnesses began in the first and second years of life (Groups 2 to 6), but the small numbers in some of these groups (for example, Groups 4 and 6) prevent firm conclusions being drawn. Children with illnesses beginning in the third, fourth, and fifth years (Groups 8, 9, and 10) had peak flow rates within the normal range.

Lower respiratory illnesses of different types (for example, wheezing, asthma, bronchitis or pneumonia) were associated with different effects on peak expiratory flow rates at the age of five as shown in Table III. Wheezing appeared to have no influence on ventilatory function on its own and the presence of wheezing in a child with bronchitis or pneumonia had no added effect on mean peak expiratory flow rate. While there were too few children with asthma alone for any worthwhile conclusions concerning its effects on lung function, those who suffered from both asthma and bronchitis or pneumonia had the lowest mean peak expiratory flow rate (119.7 litres/min) of any group.

Height and peak expiratory flow rate in children at the age of five were correlated with their parents' measurements taken the same year, as shown in Tables IV and V. The correlations between peak expiratory flow rates in parents and children (Table V) were not as strong as those seen between height in parents and children.
TABLE IV

CORRELATION OF HEIGHT BETWEEN CHILDREN AT AGE FIVE YEARS AND THEIR PARENTS

\begin{tabular}{l|c|c}
\hline & Mother & Father \\
\hline Son & $\begin{array}{l}0 \cdot 27 * * * \\
(231) \dagger\end{array}$ & $\begin{array}{c}0 \cdot 29 * * * \\
(214)\end{array}$ \\
Daughter & $\begin{array}{c}0.18^{* *} \\
(222)\end{array}$ & $\begin{array}{c}0 \cdot 30 * * * \\
(204)\end{array}$ \\
\hline
\end{tabular}

†Number of parent-child pairs with complete fifth year data. Significance of correlation coefficient:

$* * 0.001<P<0.01 ; * * * P<0.001$.

TABLE V

CORRELATION OF PEAK EXPIRATORY FLOW RATE BETWEEN CHILDREN AT AGE FIVE YEARS AND THEIR PARENTS

\begin{tabular}{l|c|c}
\hline & Mother & Father \\
\hline Son & $\begin{array}{c}0 \cdot 18^{*} \\
(231)^{\dagger}\end{array}$ & $\begin{array}{c}0 \cdot 27^{* * *} \\
(214)\end{array}$ \\
Daughter & $\begin{array}{c}0 \cdot 16^{*} \\
(222)\end{array}$ & $\begin{array}{c}0.13 \\
(204)\end{array}$ \\
\hline
\end{tabular}

+Number of parent-child pairs with complete fifth year data. Significance of correlation coefficient: $* 0.01<P<0.05$; *** $P<0.001$

No association was found between parental social class (Table VI) and children's peak expiratory flow rates at the age of five years. Area of residence did not affect peak flow rate. Parental smoking habits and respiratory morbidity also had no obvious influence.

Events during pregnancy and in the immediate postnatal period have been examined previously

TABLE III

PEAK EXPIRATORY FLOW RATES IN CHILDREN AGED FIVE YEARS BY HISTORY OF BRONCHITIS OR PNEUMONIA, ASTHMA AND/OR WHEEZING $\dagger$

\begin{tabular}{|c|c|c|c|c|c|}
\hline \multirow[t]{2}{*}{ Symptom or Illness Group } & \multirow[t]{2}{*}{$\begin{array}{l}\text { Mean PEFR* for } \\
\text { Group (litres/min) }\end{array}$} & \multirow[t]{2}{*}{ Population $\ddagger$} & \multirow[t]{2}{*}{$\begin{array}{c}\text { Standard Error } \\
\text { of Mean }\end{array}$} & \multicolumn{2}{|c|}{$\begin{array}{l}\text { Significance of Difference Between Means } \\
\text { of Groups With and Without Symptoms }\end{array}$} \\
\hline & & & & $t$ & $\mathbf{P}$ \\
\hline Nil & $151 \cdot 5$ & 292 & $1 \cdot 5$ & - & - \\
\hline Bronchitis or pneumonia only & $143 \cdot 3$ & 76 & $3 \cdot 0$ & $2 \cdot 48$ & $0.01<P<0.02$ \\
\hline Bronchitis or pneumonia with wheeze & $140 \cdot 3$ & 33 & $4 \cdot 5$ & $2 \cdot 37$ & $0.01<P<0.02$ \\
\hline $\begin{array}{l}\text { Wheezing without bronchitis or } \\
\text { pneumonia }\end{array}$ & $149 \cdot 4$ & 40 & $4 \cdot 1$ & 0.48 & $0.6<P<0.7$ \\
\hline Bronchitis or pneumonia with asthma & $119 \cdot 7$ & 10 & $8 \cdot 2$ & $3 \cdot 83$ & $P<0.001$ \\
\hline $\begin{array}{l}\text { Asthma without bronchitis or } \\
\text { pneumonia }\end{array}$ & & 3 & & & \\
\hline Total & & 454 & & & \\
\hline
\end{tabular}

* Standardized by sex and sitting height at age five years.

†Excludes 169 children for whom lung function data or respiratory illness data for the first five years of life were incomplete.

†Asthma includes children who may have had wheezing as well; wheezing excludes children who had asthma. 
TABLE VI

PEAK EXPIRATORY FLOW RATE AND SITTING HEIGHT OF CHILDREN AGED FIVE YEARS BY PATERNAL SOCIAL CLASS

\begin{tabular}{|c|c|c|c|c|c|c|}
\hline Paternal Social Class & Sex & Population $†$ & $\begin{array}{l}\text { Mean PEFR* for } \\
\text { Group (litres/min) }\end{array}$ & $\begin{array}{l}\text { Standard Error } \\
\text { of Mean }\end{array}$ & $\begin{array}{l}\text { Mean Sitting } \\
\text { Height }(\mathrm{cm})\end{array}$ & $\begin{array}{c}\text { Standard Error } \\
\text { of Mean }\end{array}$ \\
\hline I and II & $\begin{array}{l}\text { Boys } \\
\text { Girls }\end{array}$ & $\begin{array}{l}83 \\
73\end{array}$ & $\begin{array}{l}153 \cdot 0 \\
145 \cdot 6\end{array}$ & $\begin{array}{l}3 \cdot 0 \\
3 \cdot 0\end{array}$ & $\begin{array}{l}59 \cdot 3 \\
58 \cdot 9\end{array}$ & $\begin{array}{l}0.3 \\
0.3\end{array}$ \\
\hline III & $\begin{array}{l}\text { Boys } \\
\text { Girls }\end{array}$ & $\begin{array}{l}121 \\
110\end{array}$ & $\begin{array}{l}151 \cdot 2 \\
143 \cdot 8\end{array}$ & $\begin{array}{l}2 \cdot 5 \\
2 \cdot 4\end{array}$ & $\begin{array}{l}59 \cdot 6 \\
58 \cdot 8\end{array}$ & $\begin{array}{l}0.3 \\
0.3\end{array}$ \\
\hline IV and $V$ & $\begin{array}{l}\text { Boys } \\
\text { Girls }\end{array}$ & $\begin{array}{l}18 \\
29\end{array}$ & $\begin{array}{l}159 \cdot 2 \\
141 \cdot 3\end{array}$ & $\begin{array}{l}6 \cdot 4 \\
4 \cdot 8\end{array}$ & $\begin{array}{l}58 \cdot 8 \\
58 \cdot 8\end{array}$ & $\begin{array}{l}0.6 \\
0.6\end{array}$ \\
\hline Total & & 434 & & & & \\
\hline
\end{tabular}

* Standardized by sitting height at age five years.

†Excludes 189 children for whom either lung function data at age five or paternal social class data at age five were unavailable.

for effects upon ventilatory function of the infants in this sample during the first three months of life but none was found to be important (Colley 1969).

To assess the independent effects of the personal and family factors in the tables presented so far upon peak expiratory flow rate at the age of five years, a multiple regression analysis was performed using the following independent variables: age of first episode of bronchitis or pneumonia; history of asthma, wheezing, bronchitis or pneumonia; birth weight; birth length; sex; sitting height at the age of five; peak expiratory flow rates of parents (measured at the initial interview); parentait social class, smoking habits and symptoms of respiratory morbidity; bronchitis or pneumonia in siblings and number of siblings. Factors which $\$$ id not have a statistically significant effect wigre removed and the model was recalculated. Th\& significant factors from this second analysis $\$$ given in Table VII. These included a history oo bronchitis or pneumonia in the child (the eardier in life the first attack occurred, the more markee the effect), sex of child (boys had higher pear flow rates than girls), sitting height at the age of five, and father's peak expiratory flow rate.

TABLE VII OBSERVED AND ADJUSTED MEAN PEAK EXPIRATORY FLOW RATES AT AGE FIVE IN PRESENCE AND ABSENCE O SEVERAL FACTORS

\begin{tabular}{|c|c|c|c|c|}
\hline \multirow[b]{2}{*}{ Factor } & \multirow{2}{*}{$\begin{array}{l}\text { No. of } \\
\text { Subjects }\end{array}$} & \multicolumn{2}{|c|}{ PEFR (litres/min) } & \multirow{2}{*}{$\begin{array}{c}\text { Significance of Factor } \\
\text { ( } t \text { Value of Largest Difference } \\
\text { Between Means) }\end{array}$} \\
\hline & & Adjusted & Observed & \\
\hline $\begin{array}{l}\text { Time of first attack of bronchitis or } \\
\text { pneumonia } \\
\text { First year } \\
\text { 2nd-5th year } \\
\text { No attack }\end{array}$ & $\begin{array}{r}56 \\
59 \\
318\end{array}$ & $\begin{array}{l}139 \cdot 1 \\
142 \cdot 6 \\
151 \cdot 3\end{array}$ & $\begin{array}{l}137 \cdot 7 \\
142 \cdot 8 \\
151 \cdot 5\end{array}$ & $0.001<\stackrel{3 \cdot 23}{P}<0.005$ \\
\hline $\begin{array}{c}\text { Sex } \\
\text { Boys } \\
\text { Girls }\end{array}$ & $\begin{array}{l}223 \\
210\end{array}$ & $\begin{array}{l}151 \cdot 8 \\
145 \cdot 1\end{array}$ & $\begin{array}{l}152 \cdot 1 \\
144 \cdot 7\end{array}$ & $0.005 \stackrel{2.66}{P}<0.01$ \\
\hline $\begin{array}{l}\text { Sitting height in cm at age } 5 \text { years } \\
\leqslant 57 \\
58-60 \\
61+\end{array}$ & $\begin{array}{l}135 \\
165 \\
133\end{array}$ & $\begin{array}{l}140 \cdot 8 \\
150 \cdot 7 \\
153 \cdot 7\end{array}$ & $\begin{array}{l}139 \cdot 6 \\
150 \cdot 9 \\
154 \cdot 7\end{array}$ & $P \stackrel{4.06}{<0.001}$ \\
\hline $\begin{array}{l}\text { Father's peak expiratory flow rate* } \\
\leqslant 480- \\
480- \\
520- \\
560- \\
600+\end{array}$ & $\begin{array}{l}86 \\
76 \\
97 \\
85 \\
89\end{array}$ & $\begin{array}{l}141 \cdot 6 \\
146 \cdot 4 \\
150 \cdot 4 \\
147 \cdot 5 \\
156 \cdot 0\end{array}$ & $\begin{array}{l}140 \cdot 5 \\
145 \cdot 5 \\
151 \cdot 4 \\
146 \cdot 3 \\
158 \cdot 0\end{array}$ & $P<\frac{3.67}{<0.001}$ \\
\hline Total & 433 & & $148 \cdot 5$ & \\
\hline
\end{tabular}




\section{Discussion}

We found that children with a history of bronchitis, pneumonia or asthma in the preceding years had lower peak flow rates by the time they were five years old than children without such a history. The earlier the onset of these illnesses, the greater their subsequent effect on ventilatory function. Recurrent illnesses had a greater influence than single episodes, and combined episodes of asthma and bronchitis had the most powerful effect of all upon peak expiratory flow rate at the age of five. Even the more substantial differences in mean peak flow rate attributable to past lower respiratory illness were small compared with the reductions in ventilatory function observed in adults with established chronic lung disease. However, these differences could be consistent with the beginning of airways obstruction. Peak expiratory flow rate is not an especially sensitive measurement of the state of the small peripheral airways where it is thought that obstruction occurs early in the course of chronic bronchitis (Macklem, 1972).

Parental cough-phlegm, asthma-wheeze, and smoking habits, number of siblings, and sibling bronchitis or pneumonia were without apparent influence on ventilatory function in the index children. However, these same factors were found to influence the incidence of bronchitis in the first year of life in the same birth cohort (pages 203-212) The association of these factors with illness incidence, however, was noted in analyses derived from the full sample (2149 children), whereas the studies of ventilatory function were based on the one-in-three systematic sample, so relationships between these factors and ventilatory function could have been overlooked in the smaller sample. Alternatively, these factors influencing the incidence of bronchitis and pneumonia in the first year may have only an indirect, once-removed effect on ventilatory function by predisposing to infections which, in turn, lead to lung damage in some, but not all, children.

The association between peak expiratory flow rates in parents and their children in this study was similar to that found by Higgins and Keller in their comparison of forced expiratory volume in one second $\left(F E V_{1.0}\right)$ in 1000 children of all ages and their parents in Tecumseh (Higgins and Keller, 1975). However, the correlation coefficients between peak flow rate in the children and the parents were in general smaller than those of Higgins and Keller for FEV ${ }_{1.0}$. The association between parents' and child's lung function could be due to shared experience or to common genes. Twin studies may provide further information on this point.

In conclusion, recurrent respiratory illness beginning in the first year of life influenced subsequent ventilatory function of children, as measured by peak flow rate at the age of five years. During infancy, viral infections may impair the normal development of the airways and lung. Prevention of bronchitis and pneumonia in early childhood by modifying the home environment, especially by encouraging parents not to smoke (Colley, Holland, and Corkhill, 1974), is one approach that may help to reduce the immediate and distant consequences of these illnesses.

This study was supported in part by the Department of Health and Social Security. Dr S. R. Leeder was in receipt of a National Health and Medical Research Council (Australia) Clinical Sciences Fellowship. It was undertaken in conjunction with the London Borough of Harrow Health, Welfare, and Children's Department. We should particularly like to thank Miss I. Watson and Miss M. S. Hirschhorn, Superintendent Health Visitors, and their staff, and Mr G. Phipps, Senior Administrative Assistant in the Personnel Health Section and his staff, and all other individuals who took part for their help and co-operation.

We thank Miss C. Astbury, Miss S. Brenner, Miss P. Cox, Miss J. Dale, Miss H. Polak, and Miss A. Witts for maintaining the records and doing most of the field work, $\mathrm{Mr}$ Andy Thomson for his help with data processing, and Mrs Susie Gilderdale and Miss Bridget McClune for their assistance in the preparation of this paper.

Requests for reprints: R. T. Corkhill, Lecturer in Medical Statistics, Department of Community Medicine. St Thomas's Hospital Medical School, London SE1 7EH.

\section{REFERENCES}

Bland, J. M., Holland, W. W., and Elliotr, A. (1974). The development of respiratory symptoms in a cohort of Kent schoolchildren. Bull. physiopathol. Resp., 10, 699.

Colley, J. R. T. (1971). Respiratory disease in childhood. Brit. med. Bull., 27, 9.

(1969). MD thesis, University of London.

, Holland, W. W., and Corkhill, R. T. (1974). Influence of passive smoking and parental phlegm on pneumonia and bronchitis in early childhood. Lancet, 2, 1031.

and REID, D. D. (1970). Urban and social origins of childhood bronchitis in England and Wales. Brit. med. J., 2, 213.

COTES, J. E. (1974). Genetic component of lung function. Bull. physiopathol. Resp., 10, 107. 
Higgins, M. and Keller, J. (1975). Familial occurrence of chronic respiratory disease and familial resemblance in ventilatory capacity. J. chron. Dis., 28, 239.

Holland, W. W., Halil, T., Bennett, A. E., and Elliotr, A. (1969). Factors influencing the onset of chronic respiratory disease. Brit. med. J., 2, 205.
LunN, J. E., Knowelden, J., and Handyside, A. J. (1967). Patterns of respiratory illness in Sheffield infant 3 schoolchildren. Brit. J. prev. soc. Med., 21, 7.

MACKLEM. P. T. (1972). Obstruction in small airways: a challenge to medicine. Amer. J. Med., 52, 721.

WaHdan, M. H. M. E. H. (1963). Atmospheric pollution $\overline{ }$ and other environmental factors in respiratory disease of children. PhD thesis. University of London. 